\title{
Blood volume studies in chronic obstructive non-specific lung disease
}

\author{
J. B. COCKING and C.S. DARKE \\ Royal Infirmary, Sheffield and Northern General Hospital, Sheffield
}

\begin{abstract}
Blood volume studies in chronic hypoxic lung disease have produced conflicting results. Some have demonstrated that the red cell volume-hypoxic relationship is similar to that in normal subjects, whereas others have found that it is subnormal. Plasma volume has not been shown to be related to hypoxia. To elucidate this further, 45 patients with chronic obstructive bronchitis were studied. They were on average hypoxic at rest and on exertion, but mean values of red cell volume, plasma volume, venous haematocrit, red cell count, and haemoglobin concentration were normal. Red cell volume was linearly related to the degree of hypoxia, but the response was subnormal. Arterial oxygen saturation rather than tension was the main determinant of red cell volume, and resting values correlated better than exercise values with red cell volume. The best correlations were obtained when red cell volume was expressed as a function of the lean body mass rather than the total body weight. Red cell volume was also linearly related to arterial $\mathrm{Co}_{2}$ tension. Plasma volume did not correlate with any of the blood gases. The subnormal polycythaemic response to hypoxia may have been caused partially by latent iron deficiency and chronic infection; but severe hypoxia, hypercapnia, and gastrointestinal bleeding were not aetiological factors. The importance of tissue hypoxia in the regulation of the erythropoietic response and the reasons why previous blood volume studies have produced conflicting results are discussed.
\end{abstract}

There is general agreement that -red cell volume, but not plasma volume, is linearly correlated with the level of hypoxia in healthy subjects living at altitude (Shaw and Simpson, 1961 ; Weil, Jamieson, Brown, and Grover, 1968). Plasma volume is usually normal or slightly reduced at altitude (Hurtado, Merino, and Delgado, 1945; Reynafarje, Lozano, and Valdivieso, 1959 ; Pugh, 1962 ; Weil et al., 1968).

Blood volume studies in chronic obstructive non-specific lung disease have produced conflicting results. Some workers have concluded that red cell volume is not consistently elevated in a quantitatively normal manner for the level of hypoxia (Lemon, 1929 ; Kaltreider, Hurtado, and Brooks, 1934; Freedman and Penington, 1963 ; Vanier, Dulfano, Wu, and Desforges, 1963 ; Murray, 1965; Ayvazian, Richardson, and Silber, 1969). This subnormal response has been attributed in turn to severe hypoxia, hypercapnia, iron deficiency, chronic infection, and gastrointestinal bleeding. In contrast, others have demonstrated a normal red cell volume response to hypoxia in these patients (Hurtado, Merino and Delgado,
1945 ; Hammarsten, Whitcomb, Johnson, and Lowell, 1958; Shaw and Simpson, 1961 ; Lertzman, Israels, and Cherniack, 1962; Hume, 1968 ; Chan, 1969). Plasma volume is usually unrelated to hypoxia and tends to fall within the normal range, except for the studies of Shaw and Simpson (1961) and Vanier et al. (1963), in which it was increased.

This paper reports the blood volume findings $\rightarrow$ in 45 patients with chronic bronchitis and emphysema ; the results support those who maintain that a subnormal red cell volume response to hypoxia o occurs in this condition, and that plasma volume $\tilde{\sim}$ is unrelated to hypoxia.

\section{METHODS}

CRITERIA OF PATIENT SELECTION Forty-three male $\stackrel{\mathscr{Q}}{\leftrightarrow}$ and two female patients with chronic simple or mucopurulent bronchitis, as defined by the Medical Research Council Committee on the Aetiology of $\frac{\vec{D}}{\mathbb{D}}$ Chronic Bronchitis (1965), were studied. All had $\stackrel{\rho}{\mathscr{P}}$ been in a steady state clinically for the previous three $\stackrel{\mathbb{Q}}{\Omega}$ months and during that time they had not been in $\bar{\sigma}$ heart failure. Chest radiographs were compatible 
with the diagnosis of chronic bronchitis with or without emphysema, using the criteria of Laws and Heard (1962). No film showed localized lung disease, such as tuberculosis or bronchiectasis, or generalized lung disease, such as granulomata or the pneumoconioses, or primary cardiovascular or renal disease resulting in pulmonary oedema. No patient had a forced expiratory volume in 1 second $\left(F E V_{1}\right)$ greater than 1.5 litres or percentage of forced vital capacity expired in 1 second $\left(\mathrm{FEV}_{1} / \mathrm{FVC}^{\circ}\right)$ greater than $50 \%$ measured on a Godart Pulmometer (Gaensler, 1951). Patients were excluded from this study if they showed any of the following characteristics:

1. features suggestive of polycythaemia rubra vera, i.e., raised red cell count in association with splenomegaly, leucocytosis, and thrombocytosis. Patients with a raised red cell count alone were not excluded;

2. a resting blood pressure above $150 / 100 \mathrm{mmHg}$

3. clinical or electrocardiographic evidence of ischaemic heart disease;

4. gastrointestinal disease that might give rise to bleeding ;

5. significant impairment of renal or hepatic function as evidenced by abnormalities in the following investigations-urinalysis, serum urea and electrolyte concentrations, one-stage prothrombin time, serum activity of aspartate and alanine aminotransferases and alkaline phosphatase, serum concentration of bilirubin and total proteins, and serum electrophoresis.

FURTHER INVESTIGATIONS Each patient who satisfied the above criteria had the following investigations carried out.

Blood gases were estimated on arterial samples obtained through an indwelling Teflon catheter. Resting samples were taken with the patient semirecumbent; exercise samples were taken after each patient had exerted himself on an 8 in high step to a state at which he would normally stop to rest; this may or may not have been to the limits of his exercise tolerance. It was assumed that the physiological state at the end of this test would approximate to that which obtained during his daily activities. Arterial oxygen saturation $\left(\mathrm{SaO}_{2}\right)$ was measured using a Kipp Hemoreflector No. 1. Arterial oxygen tension $\left(\mathrm{PaO}_{2}\right)$, arterial carbon dioxide tension $\left(\mathrm{PaCO}_{2}\right)$, and $\mathrm{pH}$ were measured using Astrup Micro Equipment (Severinghaus and Bradley, 1958). The rebreathing $\mathrm{PaCO}_{2}$ at rest was also measured using a modified Haldane apparatus (Campbell and Howell, 1962). In addition the blood gases were determined on 22 haematologically normal control subjects who were free of cardiorespiratory disease.

Venous haematocrit was measured by the macromethod of Wintrobe, red cell count was measured using an EEL blood cell counter, and haemoglobin concentration by the cyanmethaemoglobin method; standard techniques were used to examine blood films and to calculate the red cell indices (Dacie and
Lewis, 1968a). Serum iron concentration and unsaturated iron-binding capacity were estimated on mid-morning blood samples by the method of Peters, Giovanniello, Apt, and Ross (1956). Estimation of dietary iron intake per 24 hours was obtained from a dietary history.

Alimentary blood loss was measured from the radioactivity in the stools following an intravenous injection of ${ }^{51} \mathrm{Cr}$ (Ebaugh, Clemens, Rodnan, and Peterson (1958). Red cell volumes and plasma volumes were measured concurrently using ${ }^{51} \mathrm{Cr}$ labelled erythrocytes and ${ }^{125}$ I-labelled human albumin (Weinstein, 1964); results were expressed both in millilitres per kilogramme and as a percentage of the predicted normal values. Normal blood volumes for each patient were predicted from the nomogram of Hobbs (1967). This was constructed from a height cubed body weight formula derived from the lean body mass (Nadler, Hidalgo, and Bloch, 1962). The normal red cell volumes were calculated by multiplying the predicted normal blood volume by the normal venous haematocrit (47 in males and 42 in females) corrected for trapped plasma and the normal whole body/venous haematocrit ratio $(0.91)$. Predicted plasma volumes were obtained by subtraction.

STATISTICS Significance of difference of means was determined by $t$ testing, and regression lines were determined by the method of least squares (Moroney, 1956). Calculations were carried out using an Olivetti Programma 101

\section{RESULTS}

These are recorded in Table $I$. The patients were on average underweight compared with healthy subjects. The normal weight for men aged 55 to 64 years, of height $169 \mathrm{~cm}$, was shown by Richardson and Pincherle (1969) to be $76 \mathrm{~kg}$. The mean $\mathrm{FEV}_{1}$ and $\mathrm{FEV}_{1} / \mathrm{FVC} \%$ were considerably reduced; Cotes (1965) predicts that the $\mathrm{FEV}_{1}$ of a healthy 58-year-old man should be 2.9 litres and the $\mathrm{FEV}_{1} / \mathrm{FVC}$ should be above $70 \%$.

The mean resting values of $\mathrm{SaO}_{2}, \mathrm{PaO}_{2}$, and $\mathrm{pH}$ were significantly lower $(\mathrm{P}<0.001)$ and the mean resting value of $\mathrm{PaCO}_{2}$ significantly higher $(\mathrm{P}<$ 0.001) than our control figures. After exercise mean values of $\mathrm{SaO}_{2}$ and $\mathrm{PaO}_{2}$ fell significantly compared to the resting levels $(P<0.01)$ and the patients on average became more acidotic $(\mathrm{P}<$ 0.001 ). There were no' significant differences between the means of $\mathrm{PaCO}_{2}$ at rest and after exercise.

The mean red cell and plasma volume $(\mathrm{ml} / \mathrm{kg})$ fell within the normal range, and when they were expressed as percentages of the predicted normal values the mean red cell volume was $107.3 \%$ and the mean plasma volume $98.3 \%$. Mean corpuscular volume (MCV) was increased, which is in accord with previous observations on patients with 
T A B L E I

RESULTS

\begin{tabular}{|c|c|c|c|}
\hline Investigation & Mean & S.E.M. & Normal Range ${ }^{1}$ \\
\hline $\begin{array}{l}\text { Patients with chronic } \\
\text { bronchitis } \\
\text { Age (yr) } \\
\text { Height (cm) } \\
\text { Weight (kg) } \\
\text { FEV }_{1}(\mathrm{ml}) \\
\text { FEV }_{1} / \text { FVC } \%^{2}\end{array}$ & $\begin{array}{r}58 \cdot 4 \\
169 \\
61 \cdot 3 \\
690 \cdot 0 \\
38 \cdot 4\end{array}$ & $\begin{array}{r}1.44 \\
1.21 \\
1.74 \\
31.85 \\
1.06\end{array}$ & \begin{tabular}{l|l}
$>2.9$ litres & $\begin{array}{l}\text { for } 58-y e a r \\
>70 \%\end{array}$ \\
old man, 169 \\
cm tall
\end{tabular} \\
\hline $\begin{array}{l}\mathrm{SaO}_{2} \% \\
\text { Rest }\end{array}$ & $87 \cdot 0$ & $1 \cdot 24$ & $\begin{array}{l}95-97.5 \text { (age 20) } \\
93-96 \quad \text { (age 60) }\end{array}$ \\
\hline $\begin{array}{l}\text { Exercise } \\
\mathrm{PaO}_{2}(\mathrm{mmHg}) \\
\text { Rest }\end{array}$ & $\begin{array}{l}80 \cdot 6 \\
72 \cdot 9\end{array}$ & $\begin{array}{l}1 \cdot 68 \\
2.35\end{array}$ & $\begin{array}{ll}80-100 & \text { (age } 20) \\
75-90 & \text { (age 60) }\end{array}$ \\
\hline $\begin{array}{l}\text { Exercise } \\
\text { Paco, }(\mathrm{mmHg})\end{array}$ & $61 \cdot 2$ & $2 \cdot 65$ & \\
\hline $\begin{array}{l}\text { Rest (rebreathing) } \\
\text { Rest (arterial) } \\
\text { Exercise (arterial) }\end{array}$ & $\begin{array}{l}44 \cdot 2 \\
43 \cdot 3 \\
45 \cdot 1\end{array}$ & $\begin{array}{l}1.41 \\
1.27 \\
1.49\end{array}$ & $36-47$ \\
\hline $\begin{array}{l}\text { Rest } \\
\text { Exercise } \\
\text { RCV\% \% predicted } \\
\text { ml } / \mathbf{k g}\end{array}$ & $\begin{array}{c}7 \cdot 36 \\
7 \cdot 34 \\
107 \cdot 8 \\
30 \cdot 6\end{array}$ & $\begin{array}{l}0.005 \\
0.005 \\
3.70 \\
1.01\end{array}$ & $\begin{array}{ll}26-33 & \text { (males) } \\
22-29 & \text { (females) }\end{array}$ \\
\hline $\begin{array}{l}\text { PV\% predicted } \\
\text { ml/kg } \\
\text { Venous }\end{array}$ & $\begin{array}{l}93 \cdot 3 \\
40 \cdot 9\end{array}$ & $\begin{array}{l}1 \cdot 76 \\
1 \cdot 03\end{array}$ & $22-29$ (remales) \\
\hline haematocrit \% & $49 \cdot 8$ & 0.90 & $\begin{array}{ll}40-54 & \text { (males) } \\
35-47 & \text { (females) }\end{array}$ \\
\hline RBC (million $/ \mathrm{mm}^{3}$ ) & $5 \cdot 04$ & $0 \cdot 109$ & $\begin{array}{ll}4 \cdot 5-6 \cdot 5 & \text { (males) } \\
3 \cdot 9-5 \cdot 6 & \text { (females) }\end{array}$ \\
\hline $\mathrm{Hb}(\mathrm{g} / 100 \mathrm{ml})$ & $15 \cdot 8$ & 0.26 & $\begin{array}{l}13 \cdot 5-18 \cdot 0 \text { (males) } \\
11 \cdot 5-16 \cdot 5 \text { (females) }\end{array}$ \\
\hline $\begin{array}{l}\text { Whole body/venous } \\
\text { haematocrit } \\
\text { MCV }(C \mu) \\
\text { MCHC \% } \\
\text { MCH }(\mu \mu \mathrm{g}) \\
\text { Serum iron }\end{array}$ & $\begin{array}{l}0 \cdot 86 \\
99 \cdot 1 \\
32 \cdot 0 \\
31 \cdot 6\end{array}$ & $\begin{array}{l}0 \cdot 008 \\
1 \cdot 01 \\
0 \cdot 30 \\
0 \cdot 32\end{array}$ & $\begin{array}{l}0.91 \pm 0.005 \text { S.E.M. } \\
76-96 \\
30-35 \\
27-32\end{array}$ \\
\hline $\begin{array}{l}(\mu \mathrm{g} / 100 \mathrm{ml}) \\
\mathrm{UIBC}(\mu \mathrm{g} / 100 \mathrm{ml})\end{array}$ & $\begin{array}{l}112 \cdot 7 \\
254 \cdot 8\end{array}$ & $\begin{array}{r}7 \cdot 64 \\
16 \cdot 77\end{array}$ & $\begin{array}{c}80-180^{2} \\
220-330\end{array}$ \\
\hline $\begin{array}{l}\text { Faecal blood loss } \\
\text { (ml/3 days) } \\
\text { Control subjects } \\
\mathrm{SaO}_{2} \\
\mathrm{PaO}_{2} \\
\mathrm{PaCO}_{2} \\
\text { pH }\end{array}$ & $\begin{array}{c}1 \cdot 2 \\
95 \cdot 8 \\
97 \cdot 8 \\
35 \cdot 7 \\
7 \cdot 40\end{array}$ & $\begin{array}{l}0.17 \\
0.44 \\
2.44 \\
1.53 \\
0.006\end{array}$ & $<4.5$ \\
\hline
\end{tabular}

${ }^{1}$ Normal blood gases from Cotes (1965), haematological values from Dacie and Lewis (1968b), and faecal blood loss from Grossman, Matsumoto, and Lichter (1961).

${ }^{2}$ Normal range for this laboratory.

UIBC = unsaturated iron-binding capacity.

chronic hypoxic lung disease (Wilson, Borden, and Ebert, 1951 ; Vanier et al., 1963 ; Ayvazian et al., 1969); this increase in MCV has been attributed to the direct action of hypercapnia on erythropoiesis (Price-Jones, 1921). The mean whole body/venous haematocrit ratio of $0.86 \pm 0.008$ S.E.M. was significantly lower than the value of $0.91 \pm 0.005$ S.E.M. $(\mathrm{P}<0.001)$ found in healthy subjects by Chaplin, Mollison, and Vetter (1953). The means of the remaining haematological investigations were normal.

Six patients $(13.4 \%)$ had iron deficiency in that they had low serum iron concentrations (mean $44.5 \pm 10.43$ S.E.M.) and total iron-binding capacities (mean $438 \cdot 8 \pm 47 \cdot 11$ S.E.M.) which were $16 \%$ saturated or less (Leading article, 1968); however, their red cells were morphologically normal.
This latent iron-deficient state was not explained by excessive faecal blood loss or an inadequate dietary iron intake; no patient lost an excessive amount of blood in the stools, and only one patient ingested less than $12 \mathrm{mg}$ of iron per 24 hours, which Wintrobe (1967a) considers to be the minimum daily requirement.

Six other patients were found to have an irondeficient diet. However, they did not have latent iron deficiency, anaemia, or abnormal red cells.

Another group of seven patients had low serum iron concentrations (mean 65.9 \pm 2.44 S.E.M.) with well-saturated total iron-binding capacities (mean 266.6 $\pm 27 \cdot 80$ S.E.M.) ; none was anaemic and their red cells looked either normal or macrocytic. These findings are not indicative of iron deficiency but can occur in patients with chronic infection (Cartwright et al., 1946; Cartwright and Wintrobe, 1949; Wintrobe, 1967b).

CORRELATIONS The correlations between red cell volume or plasma volume and the blood gases applicable to the patients of this study, and to the normal subjects investigated at high altitude by Weil et al. (1968), are shown in Table II ; unstandardized variates were used in each case. In their original article, Weil et al. used standardized variates to compute their correlations, which therefore differ from the values for their normal subjects appearing in Table II. An unstandardized variate is any particular measurement on which a number of readings is made, e.g., red cell volume (RCV) and $\mathrm{SaO}_{2}$, whereas a standardized variate of, say, RCV is

$$
\frac{\text { RCV - mean RCV }}{\text { Standard deviation RCV }}
$$

Red cell volume, venous haematocrit, red cell count, and haemoglobin concentration were all related to the degree of hypoxia, but correlated better with $\mathrm{SaO}_{2}$ than with $\mathrm{PaO}_{2}$. Furthermore, the resting $\mathrm{SaO}_{2}$ values gave the best correlations of all, although the mean daily $\mathrm{SaO}_{2}$ in subjects with chronic chest disease can be nearer to the exercise $\mathrm{SaO}_{2}$ level, due to the fluctuations that occur in their $\mathrm{SaO}_{2}$ throughout the day (Pierce, Jarrett, Werkle, and Miller, 1966). The red cell volume$\mathrm{SaO}_{2}$ and $\mathrm{PaO}_{2}$ regression lines shown in Figs 1 to 4 also suggest that $\mathrm{SaO}_{2}$ is the main determinant of change in red cell volume, with the best fit lines occurring with the $\mathrm{SaO}_{2}$ values. However, the patients with chest disease appeared to have a subnormal red cell volume response to hypoxia, as their red cell volume- $-\mathrm{SaO}_{2}$ regression lines in Figs 1 and 2 were shallower than those found in the healthy subjects of Weil et al. (1968) with 
T A B L E I I

CORRELATION COEFFICIENTS

\begin{tabular}{|c|c|c|c|c|c|c|c|c|c|c|}
\hline & \multicolumn{2}{|c|}{ RCV $\%$ Predicted } & \multicolumn{2}{|c|}{ RCV (ml/kg) } & \multicolumn{2}{|c|}{ PCV } & \multicolumn{2}{|c|}{$\mathbf{R B C}$} & \multicolumn{2}{|c|}{$\mathbf{H b}$} \\
\hline & $\mathbf{r}$ & $\mathbf{P}$ & $\mathbf{r}$ & $\mathbf{P}$ & $\mathbf{r}$ & $\mathbf{P}$ & $\mathbf{r}$ & $\mathbf{P}$ & $\mathbf{r}$ & $\mathbf{P}$ \\
\hline $\begin{array}{l}\text { Patients with chr } \\
\text { bronchitis } \\
\text { SaO, } \\
\text { Rest } \\
\text { Exercise } \\
\text { PaO }_{2} \\
\text { Rest } \\
\text { Exercise } \\
\text { Rebreathing } \\
\text { Paco } \\
\text { Arterial Paco, } \\
\text { Rest } \\
\text { Exercise }\end{array}$ & $\begin{array}{r}-0.681 \\
-0.635 \\
-0.447 \\
-0.532 \\
0.519 \\
0.290 \\
0.210\end{array}$ & $\begin{array}{c}<0.001 \\
<0.001 \\
<0.01 \\
<0.001 \\
<0.001 \\
<0.05 \\
\text { ns }\end{array}$ & $\begin{array}{r}-0.588 \\
-0.602 \\
-0.392 \\
-0.523 \\
0.452 \\
0.215 \\
0.226\end{array}$ & $\begin{aligned}< & 0.001 \\
< & 0.001 \\
< & 0.01 \\
< & 0.001 \\
< & 0.01 \\
& \text { ns } \\
& \text { ns }\end{aligned}$ & $\begin{array}{r}-0.623 \\
-0.560 \\
-0.399 \\
-0.494 \\
0.415 \\
0.293 \\
0.201\end{array}$ & $\begin{aligned}< & 0.001 \\
< & 0.001 \\
< & 0.01 \\
< & 0.001 \\
< & 0.01 \\
< & 0.05 \\
& \text { ns }\end{aligned}$ & $\begin{array}{r}-0.423 \\
-0.407 \\
-0.336 \\
-0.335 \\
0.308 \\
0.187 \\
0.142\end{array}$ & $\begin{aligned}<0.01 \\
<0.01 \\
<0.05 \\
<0.05 \\
<0.05 \\
\quad \text { ns } \\
\text { ns }\end{aligned}$ & $\begin{array}{r}-0.547 \\
-0.439 \\
-0.374 \\
-0.409 \\
0.380 \\
0.165 \\
0.065\end{array}$ & $\begin{aligned}< & 0.001 \\
< & 0.01 \\
< & 0.01 \\
< & 0.001 \\
< & 0.01 \\
& \text { ns } \\
& \text { ns }\end{aligned}$ \\
\hline $\begin{array}{l}\text { Normal subjects } \\
\mathrm{SaO}_{2} \\
\mathrm{PaO}_{2} \\
\text { Arterial } \mathrm{PaCO}_{2}\end{array}$ & $\begin{array}{l}-0.616 \\
-0.490 \\
-0.246\end{array}$ & $\begin{array}{l}<0.001 \\
<0.001 \\
<0.05\end{array}$ & $\begin{array}{l}-0.661 \\
-0.535 \\
-0.227\end{array}$ & $\begin{array}{l}<0.001 \\
<0.001 \\
\quad \text { ns }\end{array}$ & & & & & & \\
\hline
\end{tabular}

ns $=$ not significant at $5 \%$ level.

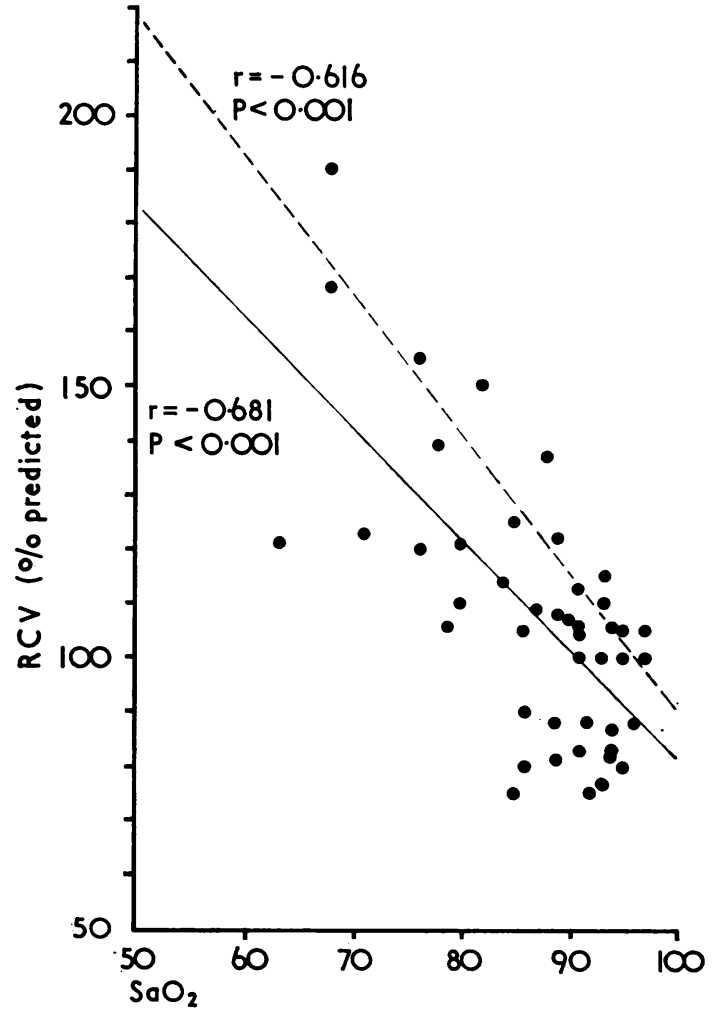

FIG. 1. Red cell volume ( $\%$ predicted $)-\mathrm{SaO}_{2}$ regressions in 45 patients with chronic bronchitis and/or emphysema (continuous line), and the normal subjects of Weil et al. (1968) (superimposed broken line). Formulae: Bronchitics $R C V=285 \cdot 1-2.04 \times S^{2} O_{2} ;$ Normals $R C V=346 \cdot 3-2.56 \times$ $\mathrm{SaO}_{2}$.

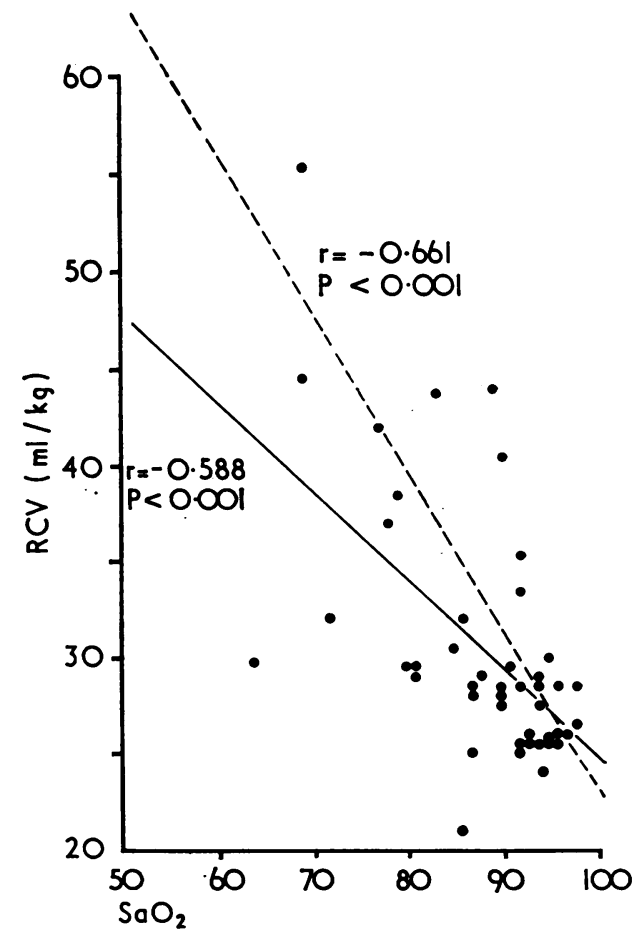

FIG. 2. Red cell volume ( $\mathrm{ml} / \mathrm{kg})-\mathrm{SaO}_{2}$ regressions in 45 patients with chronic bronchitis and/or emphysema (continuous line) and the normal subjects of Weil et al. (1968) (superimposed broken line). Formulae: Bronchitics $R C V=72.5-0.48 \times S a O_{y} ; \quad$ Normals $R C V=104.8-0.82 \times$ $\mathrm{SaO}_{2}$. 


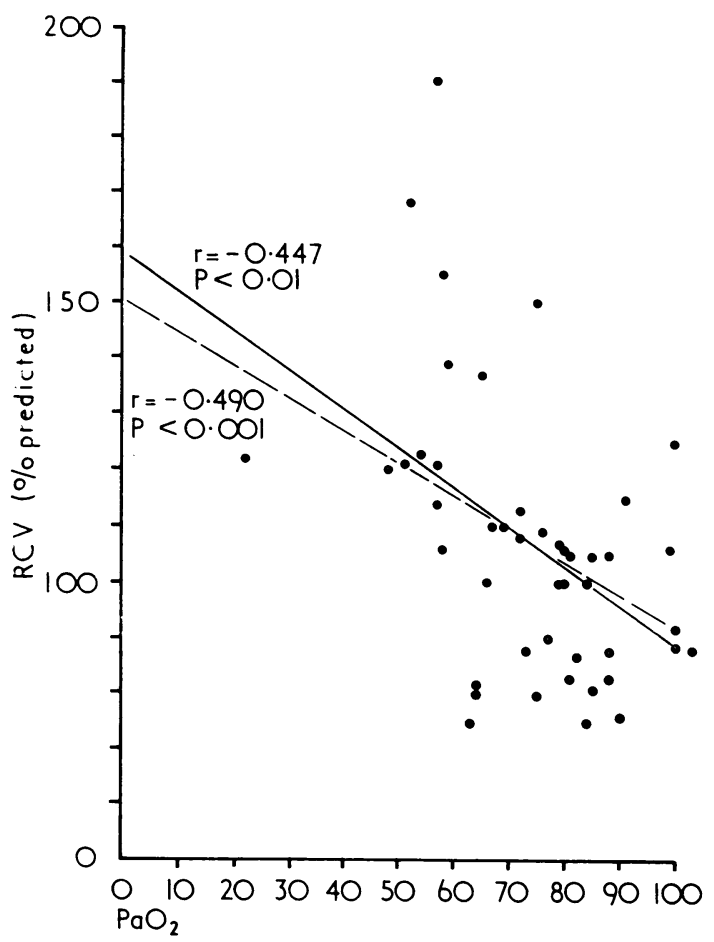

FIG. 3. Red cell volume ( $\%$ predicted $)-\mathrm{PaO}_{2}$ regressions in 45 patients with chronic bronchitis and/or emphysema (continuous line) and the normal subjects of Weil et al. (1968) (superimposed broken line). Formulae: Bronchitics $R C V=159 \cdot 2-0.70 \times \mathrm{PaO}_{2} ;$ Normals $R C V=150.4-0.59 \times$ $\mathrm{PaO}_{2}$.

intercepts on the red cell volume axes which were significantly different from normal $(t$ test, $\mathbf{P}<$ $0.001)$. It is unlikely that the differences in these regression lines are attributable to differences in technique, as similar methods were used to determine the variates in both the normal and bronchitic subjects; also, in this study these methods gave good reproducibility of results.

The best correlations between red cell volume and the level of hypoxia were obtained when red cell volume was expressed as a function of lean body mass, i.e., the fat-free mass of the body ( $\%$ predicted measurements), than as a function of total body weight $(\mathrm{ml} / \mathrm{kg}$ measurements). These findings are in accord with the previous work of Nadler et al. (1962) and others who showed that the red cell volume of an individual was dependent on his lean body mass rather than on his total body weight; this is particularly true of subjects of abnormal build, such as those studied

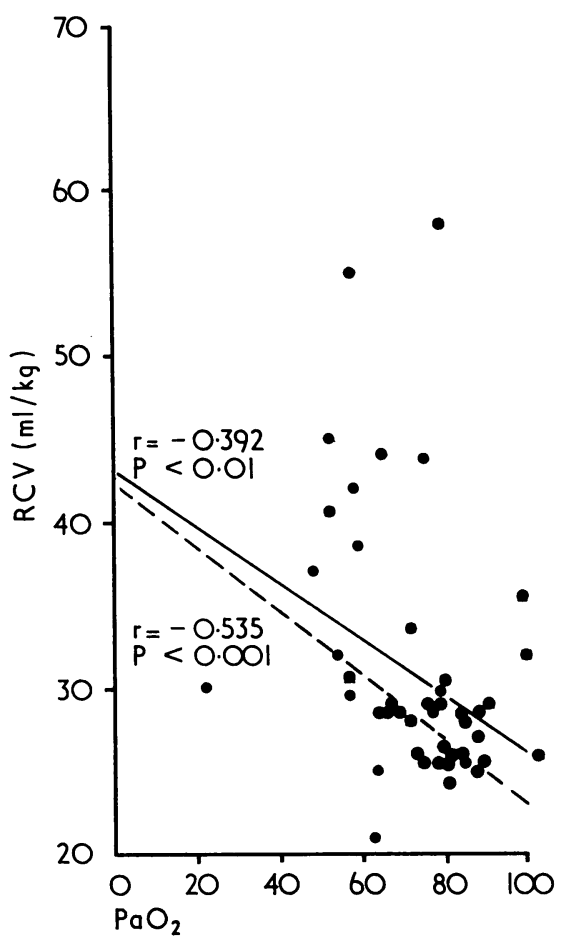

FIG. 4. Red cell volume $(\mathrm{ml} / \mathrm{kg})-\mathrm{PaO}_{2}$ regressions in 45 patients with chronic bronchitis and/or emphysema (continuous line) and the normal subjects of Weil et al. (1968) (superimposed broken line). Formulae: Bronchitics $R C V=43 \cdot 0-0.17 \times \mathrm{PaO}_{2} ; \quad$ Normals $R C V=42 \cdot 1-0 \cdot 19$ $\mathrm{PaO}_{2}$.

here, who tended to be underweight for their heights.

In the patients with chest disease, red cell volume, venous haematocrit, red cell count, and haemoglobin concentration rose in a linear manner with increasing values of the rebreathing $\mathrm{PaCO}_{2}$, and the same trend was observed with the arterial $\mathrm{PaCO}_{2}$ results. These results differ from the findings in the normal subjects of Weil et al. (1968) in whom a rise in red cell volume was associated with a slight decrease in $\mathrm{PaCO}_{2}$. However, when allowance was made for the correlation between $\mathrm{SaO}_{2}$ and $\mathrm{PaCo}_{2}(\mathrm{r}=-0.669)$ the partial coefficient of correlation between red cell volume and $\mathrm{SaO}_{2}$ was found to be -0.524 and that between red cell volume and $\mathrm{PaCo}_{2}$ to be 0.061 . Thus $\mathrm{PaCO}_{2}$ did not have any significant effect on the level of red cell volume, as the apparent red cell volume $-\mathrm{PaCO}_{2}$ relationship was primarily due to the correlation between $\mathrm{SaO}_{2}$ and $\mathrm{PaO}_{2}$. Simi- 
larly, red cell volume was not directly related to $\mathrm{pH}$, plasma volume, or $\mathrm{FEV}_{1}$.

In contrast to red cell volume, the plasma volume did not correlate with any of the blood gases or the $\mathrm{pH}$.

\section{DISCUSSION}

These results have shown that there is a linear but subnormal inverse relationship between red cell volume and $\mathrm{SaO}_{2}$ in patients with chronic bronchitis and emphysema. This observation explains why the patients in this investigation had normal mean values of red cell volume, venous haematocrit, and red cell count but were also on average hypoxic at rest due to severe ventilatory impairment. Plasma volume, in contrast to red cell volume, was unrelated to the degree of hypoxia, although its mean value was also normal.

Previous workers have put forward several suggestions to explain the subnormal polycythaemic response to hypoxia that has been observed in these patients. Thus severe hypoxia has been shown to produce bone marrow depression in vitro (Rosin and Rachmilewitz, 1948; Thomas, 1955) and was felt by Hurtado et al. (1945) to be the cause of the relative decrease in venous haematocrit and haemoglobin concentration which they observed in normal subjects at high altitude, with $\mathrm{SaO}_{2}$ levels below $65 \%$. These findings were not, however, reproduced in this study. Ratto, Briscoe, Morton, and Comroe (1955) believed that hypercapnia could cause marrow depression, but this has not been confirmed subsequently, and most investigations, including the present one, have shown that hypercapnia can be associated with increased red cell volume in patients with chronic hypoxic lung disease (Dallwig, Kolls, and Loevenhart, 1915 ; Lertzman et al., 1962 ; Hume, 1968). A proportion of these patients has been found to have iron deficiency (Shaw and Simpson, 1961; Fielding and Zorab, 1964). This occurred in six patients in this study, in whom it had not, however, affected red cell morphology. It was, therefore, unlikely to be a major factor reducing the polycythaemic response to hypoxia of the whole group. This iron-deficient state was apparently not attributable to an inadequate diet or to excessive gastrointestinal blood loss, as postulated by Simpson (1957).

Wilson et al. (1951) proposed that chronic pulmonary infection might be a possible cause of the low red cell volumes found in these patients. A number of chronic infections can develop a simple anaemia due to a combination of mild haemolysis and impaired erythropoiesis (Wintrobe, 1967b), and both these abnormalities have been demonstrated in a proportion of patients with chronic hypoxic lung disease (Gelpi, Castle, Reilly, and Searle, 1959; Lertzman et al., 1962; Ayvazian et al., 1969). Other features of the anaemia of infection, which were found in seven patients in this study, are low serum iron concentration and low total iron-binding capacity associated with red cells of normal morphology. Upon this evidence chronic pulmonary infection was probably one of the more likely causes of the subnormal polycythaemic response that was observed.

$\mathrm{SaO}_{2}$ and not $\mathrm{PaO}_{2}$ was found to be the main determinant of change in red cell volume, which is in accord with the observations of Weil et al. (1968) made on normal subjects and patients with chronic obstructive airways disease. It is unlikely that both $\mathrm{SaO}_{2}$ and $\mathrm{PaO}_{2}$ would correlate equally well with red cell volume, as their own relationship is dependent on $\mathrm{pH}$, which is itself unrelated to red cell volume. Furthermore, many of the results in the study fell in the middle of the S-shaped oxyhaemoglobin dissociation curve, where $\mathrm{SaO}_{2}$ changes relatively more than $\mathrm{PaO}_{2}$, and is, therefore, in this range the more sensitive measurement of hypoxia. $\mathrm{SaO}_{2}$ probably regulates red cell volume through its relationship with tissue hypoxia, which directly stimulates erythropoietin production. However, hypoxaemia does not always parallel tissue hypoxia, as the latter is determined by oxygen delivery to the tissues, which in turn is dependent on cardiac output, and the affinity of oxygen for haemoglobin, as well as $\mathrm{SaO}_{2}$. It is, therefore, possible for some patients to be hypoxaemic yet relatively less hypoxic in their tissues (Editorial, 1966). Thus Filley, Beckwitt, Reeves, and Mitchell (1968) found that a proportion of bronchitic subjects, although having greater hypoxaemia than others, had less tissue hypoxia because of increased cardiac output resulting in greater delivery of oxygen to the cells. In these circumstances, a quantitatively normal polycythaemic response to tissue hypoxia would appear as a subnormal response when related to the degree of hypoxaemia. A decrease in the affinity of oxygen for haemoglobin also increases oxygen delivery to the tissues as it produces a shift to the right of the oxyhaemoglobin dissociation curve; this also results in a concurrent drop in $\mathrm{SaO}_{2}$ for the same level of $\mathrm{PaO}_{2}$. Decreased oxygen affinity is found in hypoxic patients, due mainly to an intracellular increase of 2-3 diphosphoglycerate, and is a compensatory mechanism producing better tissue oxygenation which, if adequate, will 
not result in secondary erythrocytosis. However, 2-3 diphosphoglycerate concentration tends to decrease with low $\mathrm{pH}$ values, which may explain the low concentrations that sometimes occur in chronic pulmonary disease; it may also explain why some of these patients develop an erythrocytosis, whereas others-presumably those with a high 2-3 diphosphoglycerate concentrationshow a subnormal polycythaemic response to hypoxaemia, because they have satisfactory tissue oxygenation (Mulhausen, 1970; Brewer and Eaton, 1971).

There are probably several reasons why previous blood volume studies in this condition have produced conflicting results: (1) The numbers of patients studied have sometimes been too small for any valid conclusions to be derived from the results (Lemon, 1929 ; Freedman and Penington, 1963 ; Murray, 1965). (2) The blood volume results have not always been comparable, as different methods have been used to measure both red cell and plasma volumes; furthermore, most workers have measured only one volume directly and calculated the other using the whole body/ venous haematocrit ratio applicable to healthy subjects. This study has shown that this ratio is low in chronic obstructive non-specific lung disease; thus for greatest accuracy each volume should be measured separately. (3) Blood volume measurements have usually been expressed as a function of total body weight which, in patients of abnormal build, is a less accurate mode of expression than one using lean body mass. (4) Some authors have attempted to draw conclusions about the polycythaemic response in chronic chest disease from measurement of the venous haematocrit, red cell count, and haemoglobin concentration alone (Wilson et al., 1951 ; Ratto et al., 1955 ; Simpson, 1957). These give poor indications of the degree of polycythaemia and fail to differentiate between the relative and absolute varieties. (5) Earlier workers had difficulty in quantitating the red cell volume-hypoxic response in this condition, as there was little information about the relationship in healthy subjects. Only in 1961 did Shaw and Simpson calculate that a linear regression occurred in normal subjects, but the accuracy of this is questionable. They selected the physiological data from several groups permanently living at different altitudes and plotted the mean $\mathrm{SaO}_{2}$ of each group against its mean red cell volume; however, standard techniques were not used for the measurements, which were made at different times, in different parts of the world, on people of varying ethnic groups. The red cell volume $-\mathrm{SaO}_{2}$ normal regression of Weil et al. used in this study had fewer of these inherent inaccuracies, as the data were obtained from normal men of a single ethnic group living at different altitudes by identical modern methods.

We should like to thank the Heads of the following Departments who most kindly offered facilities and assistance: the Departments of Chemical Pathology, Radiology, and Respiratory Function at the Northern General Hospital, Sheffield, the University Department of Haematology and the Department of Respiratory Function at the Royal Infirmary, Sheffield, the Sheffield University Department of Preventive Medicine and Public Health and the Sheffield Regional Medical Physics Department. We gratefully acknowledge the assistance of Miss E. Picton, B.Sc., Miss E. Milne, and Mrs. D. Allen in the respiratory function measurements and blood gas analyses, Miss E. Wilson in the radioisotope determinations, Miss E. R. Read in taking the dietary histories, and Mr. A. J. Handyside, B.Sc., one-time Senior Lecturer in the University Department of Preventive Medicine and Public Health, who advised about the statistical analyses. Dr. J. V. Weil kindly allowed the use of his data obtained from normal subjects at altitude. Finally, we thank Sister Yeomans and her nursing staff at the Northern General Hospital, Sheffield, and Mrs. S. A. Montague and Miss E. Lawton for secretarial work.

\section{REFERENCES}

Ayvazian, L. F., Richardson, D. E., and Silber, R. (1969). Erythrokinetic studies during antimicrobial therapy in pulmonary emphysema. Amer. Rev. resp. Dis., $100,305$.

Brewer, G. J., and Eaton, J. W. (1971). Erythrocyte metabolism: interaction with oxygen transport. Science, 171, 1205.

Campbell, E. J. M., and Howell, J. B. L. (1962). Rebreathing method for measurement of mixed venous $\mathrm{PcO}_{2}$. Brit. med. J., 2, 630.

Cartwright, G. E., Lauritsen, M. A., Jones, P. J., Merrill, I. M., and Wintrobe, M. M. (1946). The anemia of infection. I. Hypoferremia, hyperculpremia, and alterations in porphyrin metabolism in patients. $J$. clin. Invest., 25, 65 .

— and Wintrobe, M. M. (1949). Chemical, clinical, and immunological studies on the products of human plasma fractionation. XXXIX. The anemia of infection. Studies on the iron-binding capacity of serum. $J$. clin. Invest., $28,86$.

Chan, B. W. B. (1969). Polycythaemia in coal miners with chronic lung disease. Brit. med. J., 2, 349.

Chaplin, H. Jr., Mollison, P. L., and Vetter, H. (1953). The body/venous hematocrit ratio: its constancy over a wide hematocrit range. J. clin. Invest., 32, 1309.

Cotes, J. E. (1965). Lung Function, 1st ed., p. 338. Blackwell Scientific Publications, Oxford.

Dacie, J. V., and Lewis, S. M. (1968a). Practical Haematology, 4th ed., Chapters 2 and 3, pp. 19-54 and 55-77. Churchill, London. 
(1968b). Practical Haematology, 4th ed., p. 12. Churchill, London.

Dallwig, H. C., Kolls, A. C., and Loevenhart, A. S. (1915). The mechanism adapting the oxygen capacity of the blood to the requirements of the tissues. Amer. $J$. Physiol., 39, 77.

Ebaugh, F. G. Jr., Clemens, T. Jr., Rodnan, G., and Peterson, R. E. (1958). Quantitative measurement of gastrointestinal blood loss. Amer. J. Med., 25, 169.

Editorial (1966). Hypoxemia vs. hypoxia. New Engl. J. Med., 274, 908.

Fielding, J., and Zorab, P. A. (1964). Polycythaemia and iron deficiency in pulmonary "emphysema". Lancet, 2, 284.

Filley, G. F., Beckwitt, H. J., Reeves, J. T., and Mitchell, R. S. (1968). Chronic obstructive bronchopulmonary disease. II. Oxygen transport in two clinical types. Amer. J. Med., 44, 26.

Freedman, B. J., and Penington, D. G. (1963). Erythrocytosis in emphysema. Brit. J. Haemat., 9, 425.

Gaensler, E. A. (1951). Analysis of the ventilatory defect by timed capacity measurements. Amer. Rev. Tuberc., 64, 256.

Gelpi, A. P., Castle, J. N., Reilly, W. A., and Searle, G. L. (1959). Erythrokinetics in chronic hypoxemic pulmonary emphysema. Clin. Res., 7, 84.

Grossman, M. I., Matsumoto, K. K., and Lichter, R. J. (1961). Fecal blood loss produced by oral and intravenous administration of various salicylates. Gastroenterology, 40, 383.

Hammarsten, J. F., Whitcomb, W. H., Johnson, P. C., and Lowell, J. R. (1958). The hematologic adaptation of patients with hypoxia due to pulmonary emphysema. Amer. Rev. Tuberc., 78, 391.

Hobbs, J. T. (1967). Total Blood Volume-Its Measurement and Significance, p. 12. Medical Monograph 3. The Radiochemical Centre, Amersham.

Hume, R. (1968). Blood volume changes in chronic bronchitis and emphysema. Brit. J. Haemat., 15, 131.

Hurtado, A., Merino, C., and Delgado, E. (1945). Influence of anoxemia on the hemopoietic activity. Arch. intern. Med., 75, 284.

Kaltreider, N. L., Hurtado, A., and Brooks, W. D. W. (1934). Study of the blood in chronic respiratory diseases, with special reference to the volume of the blood. J. clin. Invest., 13, 999.

Laws, J. W., and Heard, B. E. (1962). Emphysema and the chest film: a retrospective radiological and pathological study. Brit. J. Radiol., 35, 750.

Leading article (1968). Iron deficiency without anaemia. Lancet, 1, 462.

Lemon, W. S. (1929). A study of the effect of chronic pulmonary diseases on the volume and composition of the blood. Ann. intern. Med., 3, 430.

Lertzman, M., Israels, L. G., and Cherniack, R. M. (1962). Erythropoiesis and ferrokinetics in chronic respiratory disease. Ann. intern. Med., 56, 821.

Medical Research Council Committee on the Aetiology of Chronic Bronchitis (1965). Definition and classification of chronic bronchitis for clinical and epidemiological purposes. Lancet, 1, 775.
Moroney, M. J. (1956). Facts from Figures, 3rd ed. Penguin Books, Harmondsworth.

Mulhausen, R. O. (1970). Editorial. The affinity of hemoglobin for oxygen. Circulation, 42, 195.

Murray, J. F. (1965). Arterial studies in primary and secondary polycythemic disorders. Amer. Rev. resp. Dis., 92, 435.

Nadler, S. B., Hidalgo, J. U., and Bloch, T. (1962). Prediction of blood volume in normal human adults. Surgery, 51, 224.

Peters, T., Giovanniello, T. J., Apt, L., and Ross, J. F. (1956). A simple improved method for the determination of serum iron. J. Lab. clin. Med., 48, 280.

Pierce, A. K., Jarrett, C. E., Werkle, G. Jr., and Miller, W. F. (1966). Respiratory function during sleep in patients with chronic obstructive lung disease. J. clin. Invest., 45, 631 .

Price-Jones, C. (1921). The sizes of red blood cells in emphysema. J. Path. Bact., 24, 326.

Pugh, L. G. C. E. (1962). Physiological and medical aspects of the Himalayan Scientific and Mountaineering Expedition, 1960-61. Brit. med. J., 2, 621.

Ratto, O., Briscoe, W. A., Morton, J. W., and Comroe, J. H. (1955). Anoxemia secondary to polycythemia and polycythemia secondary to anoxemia. Amer. J. Med., 19, 958.

Reynafarje, C., Lozano, R., and Valdivieso, J. (1959). The polycythemia of high altitudes: iron metabolism and related aspects. Blood, 14, 433.

Richardson, J. F., and Pincherle, G. (1969). Heights and weights of British businessmen. Brit. J. prev. soc. Med., 23, 267.

Rosin, A., and Rachmilewitz, M. (1948). Studies on bone marrow in vitro. III. The effect of anoxia and hypoxia on explanted bone marrow. Blood, 3, 165.

Severinghaus, J. W., and Bradley, A. F. (1958). Electrodes for blood $\mathrm{pO}_{2}$ and $\mathrm{pCo}_{2}$ determination. J. appl. Physiol., 13, 515.

Shaw, D. B., and Simpson, T. (1961). Polycythaemia in emphysema. Quart. J. Med., 30, 135.

Simpson, T. (1957). Anoxia in emphysema: its relief by oxygen. Lancet, 2, 105.

Thomas, E. D. (1955). In vitro studies of erythropoiesis. II. The effect of anoxia on heme synthesis. Blood, 10, 612 .

Vanier, T., Dulfano, M. J., Wu, C., and Desforges, J. F. (1963). Emphysema, hypoxia and the polycythemia response. New Engl. J. Med., 269, 169.

Weil, J. V., Jamieson, G., Brown, D. W., and Grover, R. F. (1968). The red cell mass-arterial oxygen relationship in normal man. J. clin. Invest., 47, 1627.

Weinstein, V. F. (1964). Haemodilution anaemia associated with simple splenic hyperplasia. Lancet, 2, 218.

Wilson, R. H., Borden, C. W., and Ebert, R. V. (1951). Adaption to anoxia in chronic pulmonary emphysema. Arch. intern. Med., 88, 581.

Wintrobe, M. M. (1967a). Clinical Hematology, 6th ed., p. 138. Lea and Febiger, Philadelphia; Kimpton. London.

(1967b). Clinical Hematology, 6th ed., p. 573. Lea and Febiger, Philadelphia; Kimpton, London. 